\title{
Delivery of Insulin via Skin Route for the Management of Diabetes Mellitus: Approaches for Breaching the Obstacles
}

\author{
Abdul Ahad *(D), Mohammad Raish $(\mathbb{D}$, Yousef A. Bin Jardan, Abdullah M. Al-Mohizea and Fahad I. Al-Jenoobi \\ Department of Pharmaceutics, College of Pharmacy, King Saud University, P.O. Box 2457, \\ Riyadh 11451, Saudi Arabia; mraish@ksu.edu.sa (M.R.); ybinjardan@ksu.edu.sa (Y.A.B.J.); \\ amohizea@ksu.edu.sa (A.M.A.-M.); aljenobi@ksu.edu.sa (F.I.A.-J.) \\ * Correspondence: aahad@ksu.edu.sa
}

check for updates

Citation: Ahad, A.; Raish, M.; Bin Jardan, Y.A.; Al-Mohizea, A.M.; Al-Jenoobi, F.I. Delivery of Insulin via Skin Route for the Management of Diabetes Mellitus: Approaches for Breaching the Obstacles. Pharmaceutics 2021, 13, 100. https:// doi.org/10.3390/pharmaceutics 13010100

Received: 1 December 2020 Accepted: 27 December 2020 Published: 14 January 2021

Publisher's Note: MDPI stays neutral with regard to jurisdictional clai$\mathrm{ms}$ in published maps and institutional affiliations.

Copyright: (C) 2021 by the authors. Licensee MDPI, Basel, Switzerland. This article is an open access article distributed under the terms and conditions of the Creative Commons Attribution (CC BY) license (https:// creativecommons.org/licenses/by/ $4.0 /)$.

\begin{abstract}
Insulin is used for the treatment of diabetes mellitus, which is characterized by hyperglycemia. Subcutaneous injections are the standard mode of delivery for insulin therapy; however, this procedure is very often invasive, which hinders patient compliance, particularly for individuals requiring insulin doses four times a day. Furthermore, cases have been reported of sudden hypoglycemia occurrences following multidose insulin injections. Such an invasive and intensive approach motivates the quest for alternative, more user-friendly insulin administration approaches. For example, transdermal delivery has numerous advantages, such as prolonged drug release, low variability in the drug plasma level, and improved patient compliance. In this paper, the authors summarize different approaches used in transdermal insulin delivery, including microneedles, chemical permeation enhancers, sonophoresis, patches, electroporation, iontophoresis, vesicular formulations, microemulsions, nanoparticles, and microdermabrasion. Transdermal systems for insulin delivery are still being widely researched. The conclusions presented in this paper are extracted from the literature, notably, that the transdermal route could effectively and reliably deliver insulin into the circulatory system. Consistent progress in this area will ensure that some of the aforementioned transdermal insulin delivery systems will be introduced in clinical practice and commercially available in the near future.
\end{abstract}

Keywords: chronic disease; diabetes; insulin; skin; stratum corneum; transdermal

\section{Introduction}

In the last few decades, diabetes mellitus has emerged universally as an epidemic, and has become the fifth most prominent cause of mortality [1].

More than 422 million individuals worldwide have diabetes, according to a WHO report (see: https:/ / www.who.int/health-topics/diabetes\#tab=tab_1). This number could increase to 693 million by 2045 if proper actions are not taken [2,3]. In general, there are two classes of diabetes mellitus, i.e., type 1 and type 2 . Type 1 is mostly due to a total insulin deficiency, but the causes of type 2 are varying degrees of insulin resistance, impaired insulin secretion, and elevated glucose production. Type 1 may be further subcategorized into type $1 \mathrm{~A}$ diabetes mellitus, i.e., the autoimmune degradation of $\beta$-cells, and type $1 \mathrm{~B}$, i.e., idiopathic insulin deficiency [4]. The incidence of diabetes is growing owing to an aging population and improved diagnosis [5,6].

The development of insulin has been identified as one of the most significant events in the treatment of diabetes. The production of human insulin analogs using recombinant technology was seen as a huge step forward [7]. Insulin therapy has a significant role in treating type 1 diabetes. The subcutaneous route has been the most widely used, as it precludes enzymatic insulin degradation in the digestive tract. Healthy glycemic controls need to be preserved in type 1 diabetes, requiring at least three or maybe more daily insulin shots. Nevertheless, this route comes with the risk of infection and inflammation induced by the use of subcutaneous needles. Later, alternative routes-for instance, pulmonary, nasal, and oral routes-were investigated [8,9]. Pens, jet injectors, sharp needles, 
supersonic injectors, and infusion pumps have been introduced to minimize pain and enhance adherence to insulin regimens [10-13]. Still, compared to subcutaneous injections, the insulin absorption from the aforementioned techniques into the blood is quite low, and, consequently, other systems for insulin therapy are required $[14,15]$. Some noninvasive methods are being explored for insulin delivery [14]. Recently, there has been significant interest in the delivery of drugs via the transdermal route [16]. The transdermal route is an interesting choice for insulin delivery, as this approach would mitigate the pain and infection risk related to subcutaneous injections [17]. Furthermore, the transdermal route ensure patient compliance as well as delivery-controlled insulin release over time [18,19]. Still, the transdermal delivery of drugs is restricted, owing to the low permeability of the stratum corneum [20-24]. In recent years, a number of experimental techniques seeking to improve transdermal insulin delivery have been proposed [18,25-30]. In this review, different transdermal insulin delivery techniques and their improvements for diabetes care are highlighted. A schematic illustration of various strategies for insulin delivery via the transdermal route is presented in Figure 1.

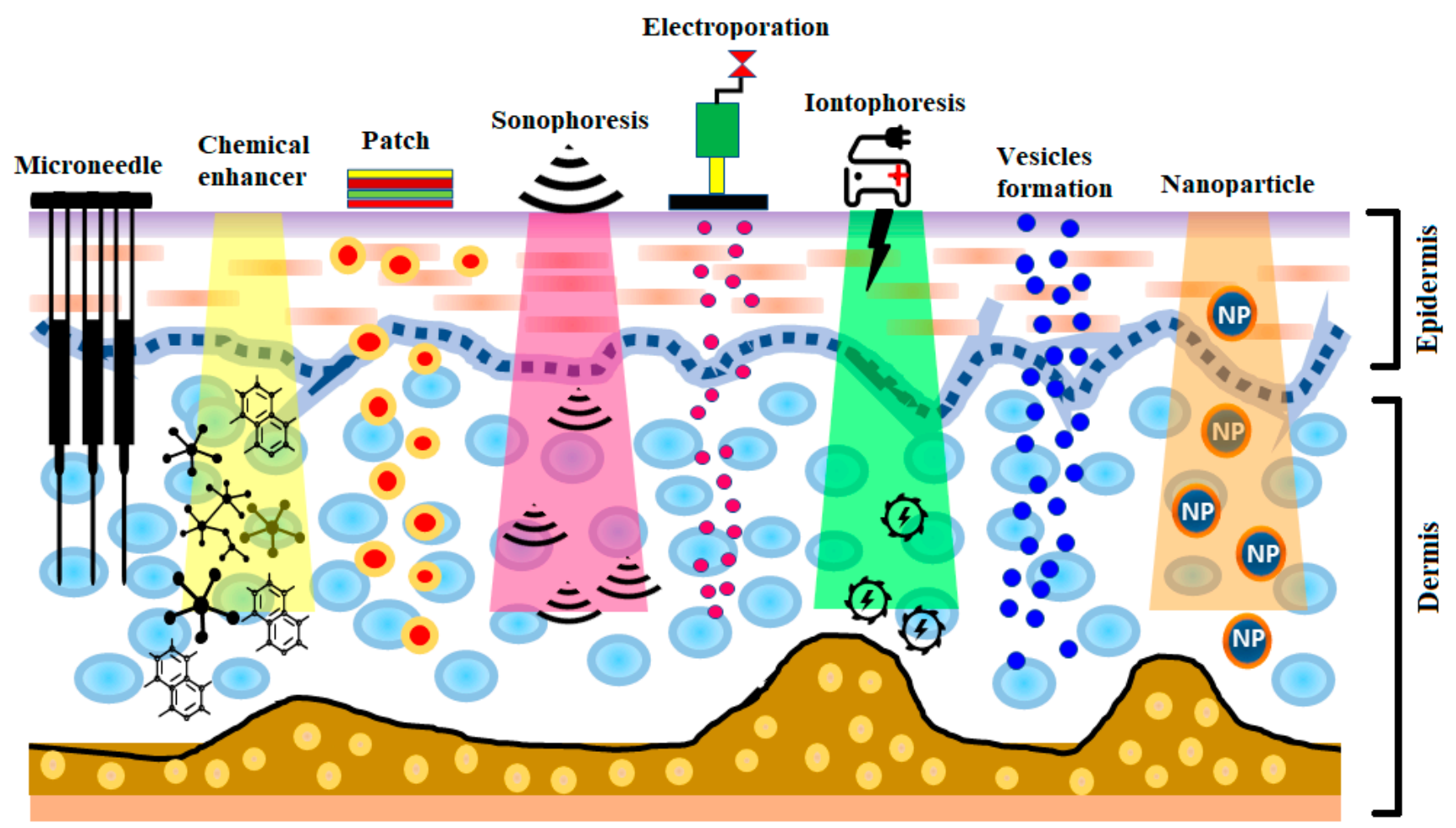

Figure 1. A schematic illustration of various strategies for insulin delivery via the transdermal route.

\section{Microneedle}

Microneedle technology offers an appealing technique for generating reversible skin microchannels that improves the skin permeability and allows the delivery of a wide variety of biotherapeutics, including insulin [31]. The delivery of microneedles at the site of application causes substantially less anxiety, pain, and tissue harm, owing to their minute size, as opposed to that of the 26-G hypodermic needle [32]. Micrometer-sized needles are sufficiently long to reach the corneum [33-36]. They are adequately narrow and sharp to cause minimal trauma and decrease the probability of infection [32,37]. This method offers a similar efficiency to standard injections. Besides this, the microneedle approach reduces the inherent problems associated with other invasive techniques [38]. Various microneedles employed for the transdermal delivery of insulin are presented in Figure 2. 


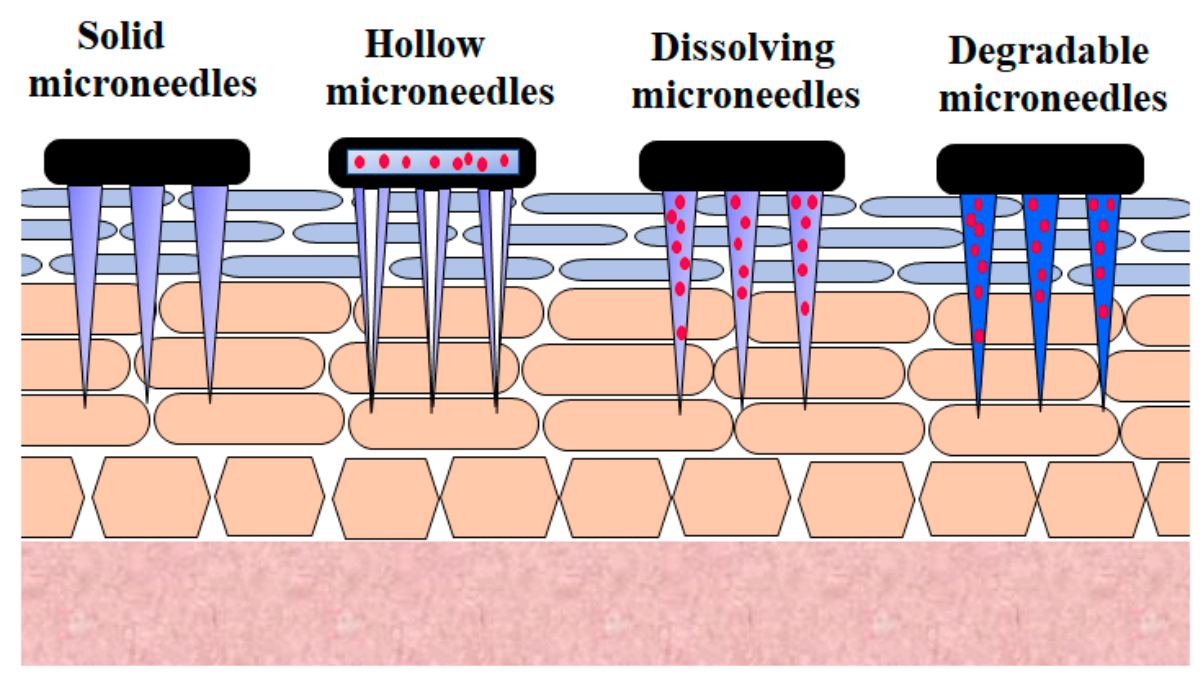

Figure 2. Various microneedles employed for transdermal insulin delivery.

Wu et al. prepared an intradermal microdelivery device consisting of a wafer with microneedles (150 $\mu \mathrm{m}$ length) for controlled insulin release. In vitro experiments showed that the level of fluorescein isothiocyanate-labeled insulin penetration after microneedle pretreatment was substantially enhanced and provided numerous upsurges after the donor phase separation. Animal studies established that the antidiabetic pattern of percutaneously administered insulin in rats was similar to that of biphasic insulin injected by the subcutaneous route [39].

The transdermal application of insulin using microneedles made of biodegradable or dissolving polymers has attracted considerable interest [40,41]. The benefit of microneedles made of polymers is that if they break down in the skin, they do not present a safety problem; rather, they simply dissolve or degrade entirely and safely. Furthermore, they are reasonably priced (compared to silicon ones). Other advantages are that drugs can be enclosed inside a microneedle polymer matrix, thereby increasing the drug loading capacity [42].

In a recent study, microneedle (dissolving polymeric) patches were developed using sodium carboxymethyl cellulose and gelatin to deliver insulin. The study results indicated that the dissolving microneedles released FITC-insulin rapidly, and then steadily disseminated the insulin into the layers of the skin. This research confirmed that insulin microneedle patches provide adequate relative bioavailability, i.e., similar to that of hypodermic injection [31].

Previously, Chen et al. prepared completely insertable microneedles, made from polyvinyl alcohol and poly-c-glutamic acid/polyvinyl pyrrolidone. The authors showed that poly-c-glutamic acid microneedles developed using a guiding structure design permitted the microneedles to be completely inserted and then distributed the insulin efficiently into the tissue. It was observed that innovations in the design of the microneedles yielded a fast, comfortable self-administration strategy for use with insulin or other therapeutic proteins [43].

In another study, Ling and Chen produced a patch containing dissolving microneedle made of gelatin and starch that liquefy within five minutes of application, rapidly releasing insulin. The authors reported that the microneedles had adequate mechanical strength to be introduced to a distance of $0.2 \mathrm{~mm}$ (in vitro) and $0.2-0.25 \mathrm{~mm}$ (in vivo) in porcine and rat skin without causing significant irritation or the sensation of pain. These insulin-loaded, quick-dissolving microneedles were applied to the rats with diabetes for in vivo analyses. Analogous antidiabetic and pharmacokinetic findings were reported in rats treated with these microneedles and a control preparation (insulin s.c. injection). The study concluded that the prepared microneedles had immense promise for the transdermal delivery of insulin [42]. 
In a previous study, Ito et al. also produced a dissolving microneedle in which 225-300 microneedles laden with insulin were assembled on a chip. Insulin-dissolving microneedles were introduced into the skin by pushing with the hand. The study noted that the depth of penetration of the microneedles was improved from 21 to $63 \mu \mathrm{m}$ at 0.8 to $2.2 \mathrm{~m} / \mathrm{s}$ in proportion to the speed of application to the isolated rat skin. Human skin showed comparable findings in terms of the depth of penetration. The developed two-layered dissolving microneedle application framework proved to be helpful for the delivery of transdermal insulin [44].

In 2012, insulin-loaded microneedle arrays made of hyaluronic acid (length: $800 \mu \mathrm{m}$; base and tip diameters: 160 and $40 \mu \mathrm{m}$, respectively) were prepared and investigated. An animal study using diabetic animals reported a dose-dependent antidiabetic outcome and only minor skin damage caused by the microneedles. The findings showed that the newly designed microneedles could become a popular option for insulin delivery without causing substantial skin injury [45].

Zhou et al. investigated the effectiveness of commercially available microneedle rollers having microneedle lengths of $0.25,0.5$ and $1.0 \mathrm{~mm}$ for transdermal insulin delivery to diabetic animals. The authors showed that microneedle rollers of 250 and $500 \mu \mathrm{m}$ were safer and very efficient devices for administering insulin transdermally in rats [46].

Still, there are lots of issues associated with microneedles from the perspective of clinical application, and this technique could attain high-efficiency, controllable, and sustained insulin delivery after overcoming such issues. First of all, the safety of the materials should be intensively tested. Second, skin allergies, redness, and irritation are the main issues attributed with the application of microneedle technology. Another drawback associated with this technology is that the microneedle can only be loaded with a small dose of medicine. In addition, if the pores on the skin created by the use of a microneedle do not close after application, there is a risk of infection. Some micromolecules might remain in the microneedles after polymerization, which could compromise the skin tissue or trigger severe reactions. Furthermore, insulin delivery strategies using microneedles should be more deeply examined to achieve the accurate and consistent delivery of insulin, since hypoglycemia could result from an overdose. Also, to begin large-scale production of microneedles and minimize costs, the fabricated approach should be streamlined. Finally, in order to verify that microneedles can effectively function in a physiological setting, additional clinical trials must be considered [47-51].

The various approaches used in the systemic delivery of insulin via the skin are addressed in the article and a summary is tabulated in Table 1.

Table 1. Various approaches used in the systemic delivery of insulin via the skin.

\begin{tabular}{|c|c|c|c|}
\hline Technique & Advantages/Disadvantages & Transdermal Research & Reference \\
\hline \multirow{7}{*}{ Microneedle } & \multirow{4}{*}{$\begin{array}{l}\text { Advantages: Possible to deliver large } \\
\text { molecules, noninvasive delivery, more } \\
\text { efficiently regulates the range of drug } \\
\text { delivery, and rapid recovery at the } \\
\text { application site compared to a } \\
\text { hypodermic needle injection [52-55]. }\end{array}$} & $\begin{array}{l}\text { Wu et al. prepared an intradermal } \\
\text { microdelivery device consist of a wafer with } \\
\text { microneedles. }\end{array}$ & [39] \\
\hline & & $\begin{array}{l}\text { Dissolving polymeric microneedle patches } \\
\text { were developed using sodium } \\
\text { carboxymethyl cellulose and gelatin. }\end{array}$ & [31] \\
\hline & & $\begin{array}{c}\text { Chen et al. introduced completely insertable } \\
\text { microneedle. }\end{array}$ & [43] \\
\hline & & $\begin{array}{l}\text { Patch contained dissolving microneedle, } \\
\text { comprising of gelatin and starch that could } \\
\text { liquefy quickly in five minutes. }\end{array}$ & [42] \\
\hline & \multirow{3}{*}{$\begin{array}{l}\text { Disadvantages: Lower dose precision } \\
\text { than hypodermic needles, frequent } \\
\text { application might trigger tissue injury, } \\
\text { tip of the microneedle may split and } \\
\text { stay inside the layer, and less than } 1 \mathrm{mg} \\
\text { of medicine may be administered by } \\
\text { bolus [55]. }\end{array}$} & $\begin{array}{l}\text { Insulin dissolving microneedles (assembled } \\
\text { on a chip) were introduced into the skin by } \\
\text { pushing with the hand. }\end{array}$ & [44] \\
\hline & & $\begin{array}{l}\text { Insulin-loaded microneedle arrays made of } \\
\text { hyaluronic acid was prepared. }\end{array}$ & {$[45]$} \\
\hline & & $\begin{array}{l}\text { Zhou et al. indicated that microneedle } \\
\text { rollers of } 250 \text { and } 500 \mu \mathrm{m} \text { are safer and more } \\
\text { efficient devices for administering insulin } \\
\text { through the transdermal route in rats. }\end{array}$ & [46] \\
\hline
\end{tabular}


Table 1. Cont.

\begin{tabular}{|c|c|c|c|}
\hline Technique & Advantages/Disadvantages & Transdermal Research & Reference \\
\hline \multirow{8}{*}{$\begin{array}{l}\text { Chemical } \\
\text { Permeation } \\
\text { Enhancer }\end{array}$} & \multirow{8}{*}{$\begin{array}{c}\text { Advantages: Design flexibility, } \\
\text { easy implementation, } \\
\text { and inexpensive [56-58]. }\end{array}$} & $\begin{array}{l}\text { Linolenic acid and oleic acid (enhancers) } \\
\text { and the microwave technique were } \\
\text { investigated to improve transdermal insulin } \\
\text { permeation. }\end{array}$ & {$[62]$} \\
\hline & & $\begin{array}{l}\text { Enhancers such as, menthone, decanol, oleic } \\
\text { acid, cycloundecanone, cis-4-hexen-1-ol, } 2 \text {, } \\
\text { 4, 6-collidine, octaldehyde, } 4 \text {-octanone, were } \\
\text { found highly enhancing and nontoxic. }\end{array}$ & [63] \\
\hline & & $\begin{array}{c}\text { The mixtures of } 1,8 \text { cineole, oleic acid, and } \\
\text { sodium deoxycholate in propylene glycol: } \\
\text { ethanol ( } 7: 3) \text { lead to in a } 45 \% \text { improvement } \\
\text { in insulin permeation in the presence of } \\
\text { iontophoresis. }\end{array}$ & {$[64]$} \\
\hline & & $\begin{array}{c}\text { Enhancers for instance, limonene, oleic, } \\
\text { linolenic, palmitic, palmitoleic, linoleic, } \\
\text { stearic, and iontophoresis were } \\
\text { investigated. }\end{array}$ & [65] \\
\hline & & $\begin{array}{l}\text { Consequence of trypsin as biochemical } \\
\text { enhancer was investigated for the } \\
\text { transdermal delivery of insulin. }\end{array}$ & {$[66,67]$} \\
\hline & & $\begin{array}{l}\text { Permeation enhancers such as } \\
n \text {-methyl-2-pyrrolidone or dimethyl } \\
\text { sulfoxide, azone into the propylene } \\
\text { glycol-drug formulations enhanced the } \\
\text { in vitro permeation of insulin. }\end{array}$ & [68] \\
\hline & & $\begin{array}{l}\text { Studied terpenes such as cineole, pulegone, } \\
\text { menthone, and menthol, in ethanol without } \\
\text { and with iontophoresis. }\end{array}$ & [69] \\
\hline & & $\begin{array}{l}\text { Both enhancers such as linoleic acid and } \\
\text { menthone demonstrated a synergistic } \\
\text { increase in insulin penetration in } \\
\text { conjunction with iontophoresis. }\end{array}$ & [70] \\
\hline \multirow{9}{*}{ Patches } & \multirow{5}{*}{$\begin{array}{l}\text { Advantages: Convenient to use, patient } \\
\text { satisfaction, reduced amounts of } \\
\text { medicine may be needed, lower } \\
\text { incidences of medication error, and } \\
\text { easy withdrawal of the patch in case of } \\
\text { any side effects [71-73]. }\end{array}$} & $\begin{array}{l}\text { Incorporation of nano-heaters into insulin } \\
\text { transdermal patches allows efficient } \\
\text { insulin release. }\end{array}$ & [75] \\
\hline & & $\begin{array}{l}\text { Transdermal lipid-based system } \\
\text { (Biphasix-insulin) was produced by King } \\
\text { et al; persistent fall in blood glucose level in } \\
\text { rats with diabetes was noted. }\end{array}$ & [29] \\
\hline & & $\begin{array}{l}\text { King et al introduced insulin in biphasic } \\
\text { vesicles-containing transdermal patches. }\end{array}$ & [76] \\
\hline & & $\begin{array}{l}\text { Mbaye et al. developed a transdermal } \\
\text { system of insulin using ethyl cellulose, } \\
\text { Eudragit RS 100, and butylphtalate. }\end{array}$ & [77] \\
\hline & & $\begin{array}{l}\text { Bohannon et al. compared the effectiveness, } \\
\text { safety, device satisfaction, and quality of life } \\
\text { of people with diabetes with an insulin } \\
\text { bolus patch. }\end{array}$ & [78] \\
\hline & \multirow{4}{*}{$\begin{array}{l}\text { Disadvantages: Slow time to peak } \\
\text { plasma levels, skin irritation; in order } \\
\text { to be successful, patches need effective } \\
\text { adhesion to the skin; factors such as } \\
\text { hairs, oil and sweat on the skin hamper } \\
\text { the adhesion of the patch and that } \\
\text { could lead to changes in the insulin } \\
\text { absorption }[73,74] \text {. }\end{array}$} & $\begin{array}{l}\text { Lyophilized hydrogel patch device for } \\
\text { microneedle-mediated insulin } \\
\text { delivery formulated. }\end{array}$ & [79] \\
\hline & & $\begin{array}{l}\text { Microfabrication technique was employed } \\
\text { for loaded insulin on a patch that had } 100 \\
\text { dissolving chondroitin sulfate microneedles. }\end{array}$ & [80] \\
\hline & & $\begin{array}{l}\text { Hadebe et al. studied pectin insulin } \\
\text { containing dermal insulin patches and } \\
\text { tested in diabetic rats. }\end{array}$ & [19] \\
\hline & & $\begin{array}{l}\text { Pectin-insulin matrix patch ameliorated the } \\
\text { diabetes indications in diabetic rats. }\end{array}$ & [81] \\
\hline \multirow{3}{*}{ Sonophoresis } & \multirow{2}{*}{$\begin{array}{l}\text { Advantages: Permits the regulation of } \\
\text { permeation rates, enables an } \\
\text { immediate end of the drug delivery, } \\
\text { less irritant, low infection risk, and less } \\
\text { painful than an injection [82-84]. }\end{array}$} & $\begin{array}{l}\text { Jabbari et al. prepared an air ultrasonic } \\
\text { ceramic transducer for transdermal } \\
\text { insulin delivery. }\end{array}$ & [86] \\
\hline & & $\begin{array}{l}\text { The involvement of cavitation in the } \\
\text { delivery of transdermal insulin } \\
\text { was explored. }\end{array}$ & [87] \\
\hline & $\begin{array}{l}\text { Disadvantages: Complicated, slight } \\
\text { tingly and burning sensation, and } \\
\text { discomfort [85]. }\end{array}$ & $\begin{array}{l}\text { Park et al. reported that the fall in the blood } \\
\text { glucose levels was considerably higher in } \\
\text { the group treated with ultrasound than } \\
\text { treated with subcutaneous injection. }\end{array}$ & [88] \\
\hline
\end{tabular}


Table 1. Cont.

\begin{tabular}{|c|c|c|c|}
\hline Technique & Advantages/Disadvantages & Transdermal Research & Reference \\
\hline \multirow{3}{*}{ Electroporation } & \multirow{2}{*}{$\begin{array}{c}\text { Advantages: Permits control of the } \\
\text { permeation rates, delivery can be } \\
\text { ceased immediately, less irritants, and } \\
\text { less painful [89]. }\end{array}$} & $\begin{array}{l}\text { Investigators demonstrated that the } \\
\text { electroporative pulses could be used in } \\
\text { diabetic rabbits to regulate the blood sugar } \\
\text { by improving insulin transportation } \\
\text { through the skin of the rabbit. }\end{array}$ & [90] \\
\hline & & $\begin{array}{l}\text { Demonstrated the beneficial consequences } \\
\text { of electroporation and iontophoresis on } \\
\text { human insulin permeation in rats. }\end{array}$ & [91] \\
\hline & $\begin{array}{l}\text { Disadvantages: Cell damage, } \\
\text { time-consuming, nonspecific [89]. }\end{array}$ & $\begin{array}{l}\text { The in vivo potency of the electroporation } \\
\text { of insulin as a solution, insulin solution } \\
\text { (s.c.), nanoparticle (i.v.) and nanoparticles } \\
\text { (electroporation) was investigated. }\end{array}$ & [92] \\
\hline \multirow{6}{*}{ Iontophoresis } & \multirow{3}{*}{$\begin{array}{l}\text { Advantages: used for unionized and } \\
\text { ionized and high molecular weight } \\
\text { molecules, delivery can be ceased } \\
\text { immediately, and improved control } \\
\text { over drug delivery [93-95]. }\end{array}$} & $\begin{array}{l}\text { Indicated that the insulin delivery by skin } \\
\text { route could be achieved by the combining } \\
\text { of iontophoresis and some enhancers. }\end{array}$ & [96] \\
\hline & & $\begin{array}{l}\text { Transdermal insulin delivery through the } \\
\text { porcine epidermis was demonstrated by } \\
\text { combining iontophoresis with different } \\
\text { chemical enhancers. }\end{array}$ & {$[64,65]$} \\
\hline & & $\begin{array}{l}\text { Simultaneous technique, such as } \\
\text { iontophoresis + electroporation, were } \\
\text { investigated for increasing insulin } \\
\text { permeation through human cadaver skin. }\end{array}$ & [97] \\
\hline & \multirow{3}{*}{$\begin{array}{l}\text { Disadvantages: time-consuming and, } \\
\text { might be harmful for budding } \\
\text { hair [93-95]. }\end{array}$} & $\begin{array}{l}\text { Demonstrated that pretreatment (wiping) of } \\
\text { skin with ethanol before iontophoresis } \\
\text { produced an impressive increment in the } \\
\text { transdermal transport of } \\
\text { monomeric insulins. }\end{array}$ & [98] \\
\hline & & $\begin{array}{l}\text { Kajimoto et al. used charged liposomes and } \\
\text { optimized iontophoretic parameters for } \\
\text { transdermal insulin delivery. }\end{array}$ & [99] \\
\hline & & $\begin{array}{l}\text { Iontophoresis-driven insulin from } \\
\text { nanovesicles via a microchannel induced by } \\
\text { microneedles in the skin, boosts the } \\
\text { transdermal delivery of insulin. }\end{array}$ & [100] \\
\hline \multirow{4}{*}{$\begin{array}{l}\text { Vesicular } \\
\text { forMulations }\end{array}$} & \multirow{2}{*}{$\begin{array}{l}\text { Advantages: versatile system could } \\
\text { entrap the miscellanea of medicine, } \\
\text { biocompatible, biodegradable, and } \\
\text { provide sustained drug } \\
\text { release }[21,101,102] .\end{array}$} & $\begin{array}{l}\text { Liposomal insulin combined with } \\
\text { D-limonene and taurocholate showed the } \\
\text { maximum hypoglycemic effect. }\end{array}$ & [103] \\
\hline & & $\begin{array}{l}\text { Demonstrated the use of ultra-deformable } \\
\text { carriers for transdermal insulin delivery. }\end{array}$ & [104] \\
\hline & \multirow[b]{2}{*}{$\begin{array}{l}\text { Disadvantages: leakage, lower stables, } \\
\text { the purity of natural phospholipids is } \\
\text { also another obstacle, and } \\
\text { expensiveness }[21,101,102]\end{array}$} & $\begin{array}{l}\text { Investigator demonstrated that } \\
\text { transferosomes could be used as potential } \\
\text { carrier for insulin. }\end{array}$ & [105] \\
\hline & & $\begin{array}{c}\text { Factorial design-based-optimized } \\
\text { insulin-transferosomes gel has shown } 13.50 \\
\pm 0.22 \mu \mathrm{g} / \mathrm{cm}^{2} / \mathrm{h} \text { transdermal flux across } \\
\text { porcine ear skin. }\end{array}$ & [106] \\
\hline \multirow{2}{*}{ Microemulsion } & $\begin{array}{l}\text { Advantages: thermodynamic stability, } \\
\text { the increased solubility and stability of } \\
\text { drugs, versatile carrier, and economical } \\
\text { scale-up [107-109]. }\end{array}$ & $\begin{array}{l}\text { Insulin emulgel was prepared using } \\
\text { emu oil. }\end{array}$ & [110] \\
\hline & $\begin{array}{l}\text { Disadvantages: leakage, phase inversion, } \\
\text { and needs the development of complex } \\
\text { systems that could be time consuming. }\end{array}$ & $\begin{array}{l}\text { Insulin-loaded microemulsion composed of } \\
\text { oleic acid }(10 \%) \text {, aqueous phase }(38 \%) \text {, and } \\
\text { surfactant phase }(50 \%) \text { with dimethyl } \\
\text { sulfoxide }(2 \%) \text { was prepared and evaluated. }\end{array}$ & [111] \\
\hline Nanoparticles & $\begin{array}{l}\text { Advantages: sustained drug release, due } \\
\text { to their nano-size particles permeate } \\
\text { efficiently across the skin, and } \\
\text { low-irritancy [112-114]. } \\
\text { Disadvantages: expensive and the } \\
\text { formulation requires special and } \\
\text { expensive techniques [112-114]. }\end{array}$ & $\begin{array}{l}\text { Prepared transdermal insulin nanoparticles } \\
\text { by means of a supercritical anti-solvent } \\
\text { micronization procedure. }\end{array}$ & [115] \\
\hline Microdermabrasion & $\begin{array}{l}\text { Advantage: efficiently increases the } \\
\text { permeability of the drug. } \\
\text { Disadvantages: expensive and, } \\
\text { skin irritation. }\end{array}$ & $\begin{array}{l}\text { Andrews et al investigated the } \\
\text { microdermabrasion technique to improve } \\
\text { the skin insulin permeability. }\end{array}$ & {$[116]$} \\
\hline
\end{tabular}




\section{Chemical Permeation Enhancer}

The term "chemical permeation enhancer" applies to a substance or mixture of substances that enhances the permeability of the skin. Several groups of permeation enhancers have been tested for the delivery of various lipophilic and hydrophilic drugs(s) using both human and animal skins $[56,117]$.

Transdermal enhancers (linolenic acid and oleic acid) and microwave techniques have recently been investigated to improve transdermal insulin permeation. The transdermal enhancer, linoleic acid, was the least active in terms of increasing the delivery of transdermal insulin, while the permeability enhancer, oleic acid, was found to be stronger than linolenic acid but failed to provide significant insulin permeation. The best result was found with microwave technology that facilitates insulin absorption and decreases the blood glucose levels in animals [62].

Previously, different chemical permeation enhancers were examined by Yerramsetty et al. to ameliorate skin permeability for the delivery of insulin. Amongst the investigated permeation enhancers, a total of eight, i.e., decanol, menthone, oleic acid, cycloundecanone, cis-4-hexen-1-ol, 2,4,6-collidine, octaldehyde, and 4-octanone, were found to be highly enhancing and nontoxic, five (cis-4-hexen-1-ol, 2,4,6-collidine, cycloundecanone, 4-octanone, and octaldehyde) of which were new discoveries [63].

Rastogi et al. assessed various transdermal enhancers in conjunction with iontophoresis; the findings indicated that the mixtures of oleic acid, 1,8 cineole and sodium deoxycholate in 3:7 ratio of ethanol:propylene glycol contributed to a $45 \%$ improvement in insulin permeation in the presence of iontophoresis, as compared to iontophoresis alone. The combinatorial use of iontophoresis with a chemical enhancer contributed to a substantial reduction in the level of glucose in blood for $8 \mathrm{~h}$ in rats with diabetes [64]. Rastogi and Singh examined the influence of limonene, linoleic, oleic, palmitic, stearic, palmitoleic, linolenic and iontophoresis on the transdermal insulin delivery via the epidermis of porcine. The authors noted that linolenic acid contributed to better iontophoretic and passive insulin permeability. The research effectively indicated the potential to deliver therapeutic insulin levels through iontophoresis in conjunction with chemical permeation enhancers [65].

In 2008 and 2009, Li et al. highlighted the influence of trypsin on the permeation of insulin via skin in rat, without and with trypsin pretreatment. The authors noted that pretreatment with $0.25 \%$ trypsin led to a 5.2 -fold increase in penetrability [66]. In addition, the FITC-insulin permeation flux was enhanced by 10-fold after pretreatment with trypsin [67]. In a separate study, the addition of permeation enhancers such as dimethyl sulfoxide, azone, or $n$-methyl-2-pyrrolidone into propylene glycol-drug formulations enhanced insulin penetration in an in vitro experiment. At $0.1 \%$ and $12.0 \%$ concentrations, azone and $n$-methyl-2-pyrrolidone demonstrated optimum efficacy. Dimethyl sulfoxide was reported to have less influence on enhancing transdermal insulin delivery than the other two investigated enhancers [68].

In another study, the influence on the transdermal delivery of insulin to rats of terpenes, such as pulegone, menthone, menthol, and cineole in ethanol, without and with iontophoresis, was investigated. With terpene in ethanol, a synergistic enhancement in the insulin flux was noted, while menthone in ethanol showed the highest improvement in flux of insulin among the terpene/ethanol combinations. Meanwhile, neat menthone presented greater insulin enhancement than menthone in ethanol. In contrast to other chemical enhancer pretreatments, iontophoresis had a lower influence on the skin obstacle properties. Terpene in ethanol mediated a synergistic improvement of insulin permeation when combined with iontophoresis [69]. Later, a gel preparation of insulin using poloxamer 407 was prepared by Pillai and Panchagnula. In ex vivo tests, both linoleic acid and menthone demonstrated a synergistic increase in insulin penetration in conjunction with iontophoresis. A decrease in the plasma glucose level of $36-40 \%$ was achieved by iontophoresis alone or in conjunction with linoleic acid. The authors noted that more skin discomfort was caused by the chemical enhancers when combined iontophoresis than when each was used alone [70]. 


\section{Patches}

In particular, transdermal patches are an appealing dosage method for the predictable and consistent delivery of insulin into the bloodstream. Insulin patches contribute to patient-friendly, noninvasive and painless delivery of insulin. Even, in the case of hyperinsulinemia, patients can easily remove the patches. Recently, nanoheaters incorporated into insulin patches were shown to effectively release insulin, and demonstrated comparable in vivo activity in mice with respect to s.c. injection of insulin [75].

In 2002, an innovative transdermal lipid-based system (Biphasix-insulin) was produced by King et al. and tested for blood glucose-reducing efficacy in a diabetic rat model induced by streptozotocin. Biphasix-insulin-containing transdermal patches (recombinant human insulin dose $10 \mathrm{mg}$ ) were administered to abdominal skin of rats with diabetes for $48 \mathrm{~h}$. A blood glucose level decrease of $43.7 \%$, compared to initial values, was observed. Further, the insulin bioavailability was improved by $21.5 \%$, based on the serum insulin noted from the transdermal Biphasix-insulin patches. It was concluded that the Biphasix device successfully administered insulin via the skin route. These findings support the use of patches containing insulin for human use [29]. In 2003, King et al. reported that insulin in biphasic vesicle-containing transdermal patches had been administered to the abdominal skin of diabetic rats for $73 \mathrm{~h}$, and the levels of blood glucose tested using a glucose meter every 2-10 h. ELISA was used to measure the inguinal lymph node insulin samples. The findings showed that insulin increased in the lymph nodes in a manner that depended on the dose and time. The maximum transdermal lymph node insulin concentrations were reported at $73 \mathrm{~h}$ with both $140 \mathrm{IU}$ and $280 \mathrm{IU}$ doses of recombinant insulin. The authors concluded that lymph transport is involved after transdermal insulin delivery of biphasic vesicles [76].

In another study, Mbaye et al. utilized Eudragit RS 100, butylphtalate, and ethyl cellulose to formulate a transdermal insulin system, and found that the continuous release profiles strongly depended on Ethylcellulose/Eudragit [77]. In 2011, Bohannon et al. noted that bolus insulin is easier to obtain, and that it increases quality of life of diabetic subjects [78]. Another study by Qiu et al. described a lyophilized hydrogel patch device for microneedle-mediated insulin delivery. The authors noted that blood glucose was reduced in rats, and action was maintained for longer, compared to subcutaneous injection [79].

In another report, a microfabrication technique was employed to load insulin onta a patch that had 100 dissolving chondroitin sulfate microneedles. By using two or four patches on the (abdominal) skin of dogs, the antidiabetic effects were evaluated, and samples of blood taken, for $6 \mathrm{~h}$. The insulin content per established patch was 1.67 IU. For two patches, a minimum level of glucose plasma was observed at $0.83 \mathrm{~h}$, while for four patch trials, this occurred at $1.37 \mathrm{~h}$. The findings showed that the bioavailability of microneedle insulin was found to be $72.1 \%$ for two patches and $72.4 \%$ for four patches. Furthermore, researchers noted that insulin was stable at $4{ }^{\circ} \mathrm{C}$ for one month in the dissolved microneedles, after which the recovered percentage was found to be $99.2 \pm 13.9 \%$ [80].

Hadebe et al. studied pectin insulin-containing dermal insulin patches and tested them on diabetic rats. The authors found that the oral glucose test responses of treated rats with transdermal pectin insulin patches displayed reduced blood glucose levels after five weeks, while short-run therapies restored the glycogen levels of both liver and muscle. The produced pectin insulin matrix patch provided regulated insulin release and relieved a variety of diabetic symptoms [19]. In another report, the use of the matrix patch of pectin-insulin was shown to offer protection against the devastating cardiovascular effects associated with the conventional treatment of diabetes [81].

\section{Sonophoresis}

The use of ultrasound to enhance transdermal drug transport is referred to as phonophoresis or sonophoresis (Figure 3) [118]. It was observed that the increase in insulin delivery by the skin route that resulted from the use of ultrasound waves (lowfrequency $20-100 \mathrm{kHz}$ ) could be due to the disruption of stratum corneum layers [119,120]. 
While sonophoresis has received considerable attention from researchers, its mechanisms are not fully understood, although several probable mechanisms have been suggested, the most plausible of which is cavitation [121,122].

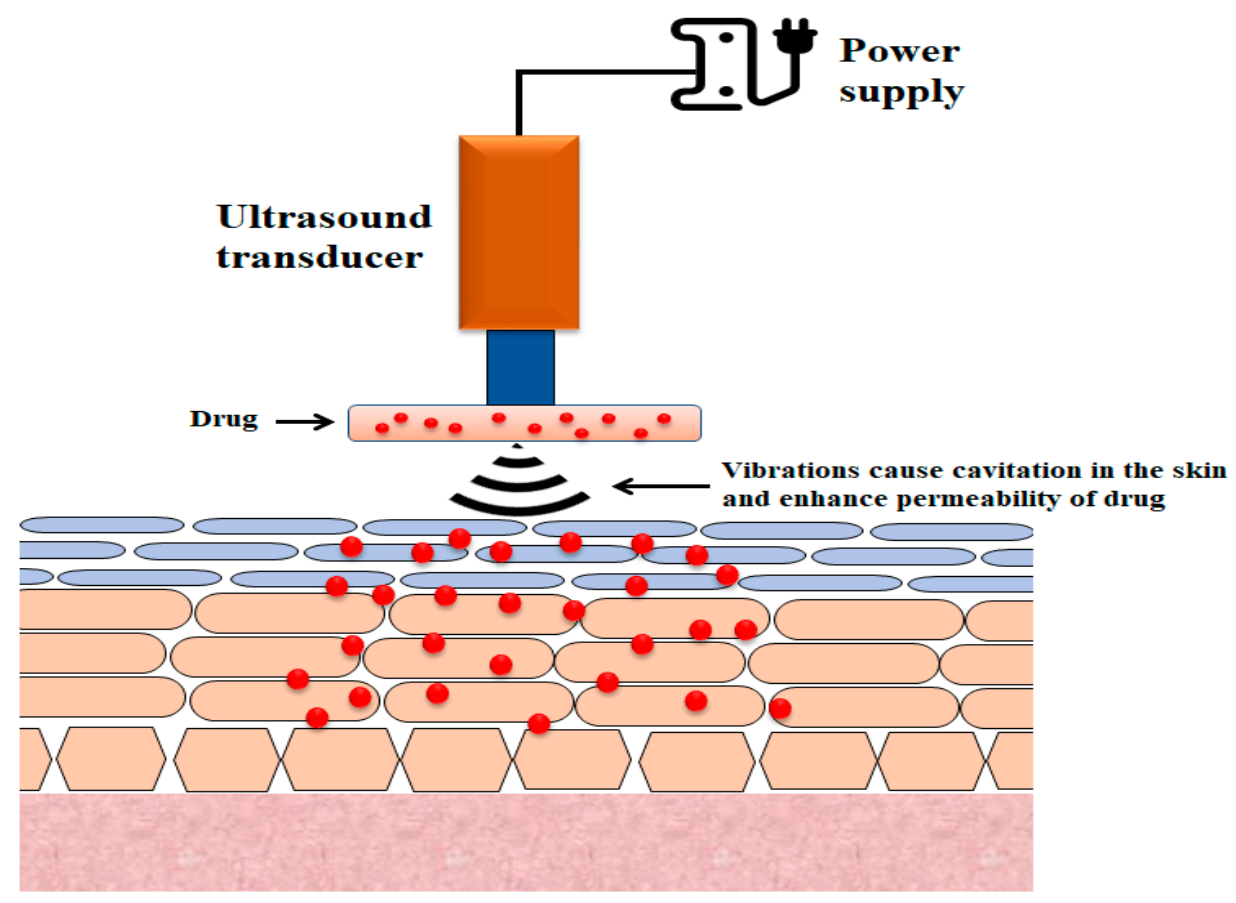

Figure 3. Illustration of the basic design of sonophoretic delivery devices.

The air ultrasonic ceramic transducer for insulin transdermal delivery was developed by Jabbari et al. In their study, rats were divided into four groups: Group 1 was a control group; Group 2 received a subcutaneous injection of insulin $(0.25 \mathrm{U} / \mathrm{Kg})$; Topical and ultrasonic transdermal insulin were administered to groups 3 and 4 respectively. The investigators indicated that the application of ultrasound technique ameliorated insulin delivery, and that the diabetic glucose level of rats was reduced to normal values [86]. In another study, the involvement of cavitation in the delivery of transdermal insulin was explored, and substantial improvement in insulin penetration (40\%) was reported [87]. In past research, the physiological reaction to transdermal insulin delivery mediated by ultrasound was shown to correlate with that of insulin administered subcutaneously. In this study, blood glucose levels declined by $190 \pm 96 \mathrm{mg} / \mathrm{dL} 1.5 \mathrm{~h}$ after insulin administration (subcutaneous injection $0.25 \mathrm{U} / \mathrm{kg}$ dose), whereas blood glucose decreased by $263 \pm 40 \mathrm{mg} / \mathrm{dL}$ at $1.5 \mathrm{~h}$ with insulin delivered with ultrasound [88].

\section{Electroporation}

In this process, short, high-voltage electric field signals generate transient aqueous paths in the stratum corneum [123-126]. Researchers showed that electroporative pulses could be used in diabetic rabbits to regulate blood sugar by improving insulin transportation through the skin. It was highlighted that the increment in insulin dose and electroporative pulses, and decrease in the field strength of electroporation, contributed to a dramatic reduction in the blood sugar levels [90]. In the original report, investigators used a combination of electroporation and iontophoresis to study insulin permeation in rats. The investigators found that the combination of these techniques led to an increase in insulin plasma levels in comparison to those reported following electroporation [91]. In another study, an in vivo potency of the electroporation of insulin as a solution, insulin solution (s.c.), nanoparticle (i.v.) and nanoparticles (electroporation) was discussed. These findings indicated that polymeric nanosystem electroporation was an attractive substitute to injectable administration [127]. Other research indicated that, compared to 
electroporation alone, electroosmosis combined with electroporation in the presence of 1,2-dimyristoylphophatidylserine (a saturated anionic lipid) contributed a substantially higher transport rate of insulin [92].

\section{Iontophoresis}

One possible method for the improvement of drug delivery is transdermal iontophoresis $[128,129]$. Hao et al. stated that transdermal insulin delivery could potentially be achieved by combining iontophoresis and some enhancers [96]. Elsewhere, transdermal insulin delivery through porcine epidermis was observed by combining the use of iontophoresis with different chemical enhancers [64,65]. In 2002, researchers demonstrated the application of simultaneous techniques, such as iontophoresis + electroporation, for insulin permeation augmentation through human cadaver skin ex vivo [97]. Transdermal insulin delivery using the technique of iontophoresis was demonstrated in [26,69,130-133]. In a prior study, pretreatment (wiping) of skin using alcohol before iontophoresis was said to produce an impressive increment in insulin transdermal transport [98].

Kajimoto et al. indicated that a progressive drop in the levels of blood glucose in rats with diabetes occurred when employing insulin- liposome and iontophoresis combinations [99]. In other research, the authors verified that the permeation of insulin-loaded, positively-charged nanovesicles-applied via iontophoresis to skin with microchannels created by a microneedle-was 713.3 times greater, compared to the use of nanovesicles. Animal experiments showed that the level of blood glucose in rats with diabetes dropped considerably (comparable to an s.c. injection of insulin) at $4 \mathrm{~h}$ and $6 \mathrm{~h}$ following the combined application of positive nanovesicles driven by iontophoresis and microneedles [100].

\section{Vesicular Formulations}

Liposomes are widely-studied nano-sized lipid vesicles that could be beneficial in the delivery of drugs via the dermal or transdermal routes. Liposomes, as drug carriers, offer many advantages that are reported elsewhere [134-136].

Techniques such as using combinations of two or more enhancers or the liposomal formula of insulin were investigated by Ogiso et al. The highest blood sugar lowering action that continued up to $10 \mathrm{~h}$ was exhibited by a transdermal system comprising liposomes insulin, D-limonene, and taurocholate. A high hypoglycemia effect was also achieved with a blend of $n$-octyl-beta-D-thioglucoside, cineol, and deoxycholate, or D-limonene and $n$-octyl-beta-D-thioglucoside. The authors clearly showed that the absorption of insulin in the stratum corneum of rat skin could be achieved under certain circumstances [103].

Transferosomes are highly elastic vesicles that are comprised of phospholipids and edge activators $[137,138]$. They can permeate the skin and are an efficient means by which to deliver entrapped drugs when applied in nonoccluded circumstances [139]. The highly flexible vesicles, named "transferosomes", were shown to be good drug carriers if loaded with insulin and applied in acceptable quantities [28,104].

The rotary evaporation sonication technique was used to prepare a transdermal transferosome insulin gel. The results showed that the optimized formulation entrapment efficiency of insulin was $78 \%$, and a cumulative release of insulin of $83.11 \%$ was observed. In vivo tests clearly showed that a better effect on glucose reduction was achieved by insulin transferosome gels compared to a control gel. The authors concluded that their study showed that the prepared transferosomal formulation could be used as a potential carrier for insulin and other protein deliveries [105]. In an earlier study, optimized insulin-containing transferosome gels were also produced on the basis of a factorial design that showed good permeation flux, i.e., $13.50 \pm 0.22 \mu \mathrm{g} / \mathrm{cm}^{2} / \mathrm{h}$, across ear skin of porcine. An increased in permeation flux of $17.60 \pm 0.03 \mu \mathrm{g} / \mathrm{cm}^{2} / \mathrm{h}$ was obtained by further applying the technique of insulin transferosomes with iontophoresis. The animal study revealed that the best transferosome gels exhibited sustained hypoglycemic effects over $24 \mathrm{~h}$ in diabetic rats [106]. 


\section{Microemulsion}

Microemulsions typically droplets of less than $100 \mathrm{~nm}$ in size, and are thermodynamically stable clear liquids [140-142]. Microemulsions have been extensively studied and have gained considerable interest as vehicles of transdermal administration [143-148].

In 2013, insulin emulgel was prepared using emu oil (composed of fatty acids obtained from emu, a bird, Dromaius Novae-Hollandiae, native to Australia) as a permeation enhancer. The biological activity of emulgel alone and in combination with iontophoresis was tested using albino rabbits. The authors claimed that the optimized formulation [F4: emu oil $(7.5 \% w / w)$ and polysorbate $80(5.0 \% w / w)]$ showed a maximum insulin permeation flux of $4.88 \mu \mathrm{g} / \mathrm{cm}^{2} / \mathrm{h}$ through rat skin. A pharmacodynamic study indicated that the blood glucose level decreased from an initial value of $250 \mathrm{mg} / \mathrm{dL}$ to $185 \mathrm{mg} / \mathrm{dL}$ and the initial value to $125 \mathrm{mg} / \mathrm{dL}$ in $2 \mathrm{~h}$ in the group treated with insulin emulgel alone and insulin emulgel + iontophoresis respectively [110].

Transdermal microemulsions containing insulin were formulated with $10 \%$ oleic acid, $50 \%$ surfactant phase, and $2 \%$ DMSO, providing a maximum flux of $4.93 \mu \mathrm{g} / \mathrm{cm}^{2} / \mathrm{h}$ across goat skin. The authors concluded that there was considerable potential to use microemulsions for insulin delivery via the skin route [111].

\section{Nanoparticles}

Earlier, the feasibility of the use of transdermal insulin nanoparticles by means of a supercritical antisolvent micronisation procedure was investigated. The authors indicated that the supercritical antisolvent procedure provided uniform spherical insulin nanoparticles of particle sizes $68.2 \pm 10.8 \mathrm{~nm}$. The research indicated that the supercritical antisolvent process did not cause insulin degradation. An in vitro evaluation revealed that the insulin nanoparticles followed Fick's first diffusion law, and displayed a good permeation rate. The authors found that the prepared nanoparticles containing insulin may have promising possibilities for the transdermal delivery of diabetes chemotherapy [115].

\section{Microdermabrasion}

Microdermabrasion has been previously used to minimize the presence of wrinkles, scars, and fine lines [149-151]. Previously, this approach was adopted as a tool to mitigate the hindering nature of the stratum corneum [152-155].

The application of microdermabrasion to improve skin insulin permeability was investigated by Andrews et al., who highlighted that microdermabrasion could improve the permeability of the skin to insulin at levels that are adequate to stabilize the range of blood glucose in rats with diabetes [116].

\section{Conclusions}

Chronic diseases such as diabetes are among the most prominent causes of mortality, morbidity, and high health-care costs. For individuals with diabetes, regular shots of insulin are required to maintain normal blood glucose levels. Other techniques for insulin delivery possess some disadvantages. Hence, there is a vital need to find new approaches for insulin delivery. Transdermal drug delivery presents exciting possibilities, as it eliminates the pain and risk of infection associated with subcutaneous insulin injections, ensures patient compliance, and provides a controlled release of insulin. It was observed from the literature that the different transdermal techniques reported in this article have been widely and successfully used for the delivery of insulin. Encouraging developments are occurring which will lead to the more successful and safe delivery of insulin via the transdermal route.

Funding: Deputyship for Research and Innovation, 'Ministry of Education' Saudi Arabia: IFKSURP-244.

Institutional Review Board Statement: Not applicable.

Informed Consent Statement: Not applicable.

Data Availability Statement: Not applicable. 
Acknowledgments: The authors extend their appreciation to the Deputyship for Research and Innovation, 'Ministry of Education' in Saudi Arabia for funding this research work through the Project no. (IFKSURP-244).

Conflicts of Interest: The authors declare no conflict of interest.

\section{References}

1. Tabish, S.A. Is Diabetes Becoming the Biggest Epidemic of the Twenty-first Century? Int. J. Health Sci. (Qassim) 2007, 1, V-VIII.

2. Lin, X.; Xu, Y.; Pan, X.; Xu, J.; Ding, Y.; Sun, X.; Song, X.; Ren, Y.; Shan, P.F. Global, regional, and national burden and trend of diabetes in 195 countries and territories: An analysis from 1990 to 2025. Sci. Rep. 2020, 10, 14790-14801. [CrossRef] [PubMed]

3. Zhao, R.; Lu, Z.; Yang, J.; Zhang, L.; Li, Y.; Zhang, X. Drug Delivery System in the Treatment of Diabetes Mellitus. Front. Bioeng. Biotechnol. 2020, 8, 880. [CrossRef] [PubMed]

4. Rai, V.K.; Mishra, N.; Agrawal, A.K.; Jain, S.; Yadav, N.P. Novel drug delivery system: An immense hope for diabetics. Drug Deliv. 2016, 23, 2371-2390. [CrossRef] [PubMed]

5. Saeedi, P.; Petersohn, I.; Salpea, P.; Malanda, B.; Karuranga, S.; Unwin, N.; Colagiuri, S.; Guariguata, L.; Motala, A.A.; Ogurtsova, K.; et al. Global and regional diabetes prevalence estimates for 2019 and projections for 2030 and 2045 : Results from the International Diabetes Federation Diabetes Atlas, 9(th) edition. Diabetes Res. Clin. Pract. 2019, 157, 107843. [CrossRef] [PubMed]

6. Cheng, Y.J.; Kanaya, A.M.; Araneta, M.R.G.; Saydah, S.H.; Kahn, H.S.; Gregg, E.W.; Fujimoto, W.Y.; Imperatore, G. Prevalence of Diabetes by Race and Ethnicity in the United States, 2011-2016. JAMA 2019, 322, 2389-2398. [CrossRef]

7. Rosenfeld, L. Insulin: Discovery and controversy. Clin. Chem. 2002, 48, 2270-2288. [CrossRef] [PubMed]

8. Verma, A.; Kumar, N.; Malviya, R.; Sharma, P.K. Emerging Trends in Noninvasive Insulin Delivery. J. Pharm. (Cairo) 2014, 2014, 378048. [CrossRef] [PubMed]

9. Mo, R.; Jiang, T.; Di, J.; Tai, W.; Gu, Z. Emerging micro- and nanotechnology based synthetic approaches for insulin delivery. Chem. Soc. Rev. 2014, 43, 3595-3629. [CrossRef] [PubMed]

10. Al-Tabakha, M.M.; Arida, A.I. Recent challenges in insulin delivery systems: A review. Indian J. Pharm. Sci. 2008, 70, 278-286. [CrossRef] [PubMed]

11. Kesavadev, J.; Saboo, B.; Krishna, M.B.; Krishnan, G. Evolution of Insulin Delivery Devices: From Syringes, Pens, and Pumps to DIY Artificial Pancreas. Diabetes Ther. 2020, 11, 1251-1269. [CrossRef] [PubMed]

12. Selam, J.L. Evolution of diabetes insulin delivery devices. J. Diabetes Sci. Technol. 2010, 4, 505-513. [CrossRef] [PubMed]

13. Penfornis, A.; Personeni, E.; Borot, S. Evolution of devices in diabetes management. Diabetes Technol. Ther. 2011, 13, S93-S102. [CrossRef] [PubMed]

14. Yaturu, S. Insulin therapies: Current and future trends at dawn. World J. Diabetes 2013, 4, 1-7. [CrossRef] [PubMed]

15. Gradel, A.K.J.; Porsgaard, T.; Lykkesfeldt, J.; Seested, T.; Gram-Nielsen, S.; Kristensen, N.R.; Refsgaard, H.H.F. Factors Affecting the Absorption of Subcutaneously Administered Insulin: Effect on Variability. J. Diabetes Res. 2018, 2018, 1205121. [CrossRef]

16. Al Hanbali, O.A.; Khan, H.M.S.; Sarfraz, M.; Arafat, M.; Ijaz, S.; Hameed, A. Transdermal patches: Design and current approaches to painless drug delivery. Acta Pharm. 2019, 69, 197-215. [CrossRef] [PubMed]

17. El Khafagy, S.; Morishita, M.; Onuki, Y.; Takayama, K. Current challenges in non-invasive insulin delivery systems: A comparative review. Adv. Drug Deliv. Rev. 2007, 59, 1521-1546. [CrossRef] [PubMed]

18. Ng, L.C.; Gupta, M. Transdermal drug delivery systems in diabetes management: A review. Asian J. Pharm. Sci. 2020, 15, 13-25. [CrossRef] [PubMed]

19. Hadebe, S.I.; Ngubane, P.S.; Serumula, M.R.; Musabayane, C.T. Transdermal delivery of insulin by amidated pectin hydrogel matrix patch in streptozotocin-induced diabetic rats: Effects on some selected metabolic parameters. PLoS ONE 2014, 9, e101461. [CrossRef] [PubMed]

20. Antunes, E.; Cavaco-Paulo, A. Stratum corneum lipid matrix with unusual packing: A molecular dynamics study. Colloids Surf. B Biointerfaces 2020, 190, 110928. [CrossRef] [PubMed]

21. Opatha, S.A.T.; Titapiwatanakun, V.; Chutoprapat, R. Transfersomes: A Promising Nanoencapsulation Technique for Transdermal Drug Delivery. Pharmaceutics 2020, 12, 855. [CrossRef] [PubMed]

22. Fernandez-Garcia, R.; Lalatsa, A.; Statts, L.; Bolas-Fernandez, F.; Ballesteros, M.P.; Serrano, D.R. Transferosomes as nanocarriers for drugs across the skin: Quality by design from lab to industrial scale. Int. J. Pharm. 2020, 573, 118817. [CrossRef] [PubMed]

23. Mitragotri, S.; Farrell, J.; Tang, H.; Terahara, T.; Kost, J.; Langer, R. Determination of threshold energy dose for ultrasound-induced transdermal drug transport. J. Control. Release 2000, 63, 41-52. [CrossRef]

24. Prausnitz, M.R.; Langer, R. Transdermal drug delivery. Nat. Biotechnol. 2008, 26, 1261-1268. [CrossRef]

25. Sen, A.; Daly, M.E.; Hui, S.W. Transdermal insulin delivery using lipid enhanced electroporation. Biochim. Biophys. Acta 2002, 1564, 5-8. [CrossRef]

26. Pillai, O.; Borkute, S.D.; Sivaprasad, N.; Panchagnula, R. Transdermal iontophoresis of insulin. II. Physicochemical considerations. Int. J. Pharm. 2003, 254, 271-280. [CrossRef]

27. Sintov, A.C.; Wormser, U. Topical iodine facilitates transdermal delivery of insulin. J. Control. Release 2007, 118, 185-188. [CrossRef] [PubMed] 
28. Cevc, G.; Gebauer, D.; Stieber, J.; Schatzlein, A.; Blume, G. Ultraflexible vesicles, Transfersomes, have an extremely low pore penetration resistance and transport therapeutic amounts of insulin across the intact mammalian skin. Biochim. Biophys. Acta 1998, 1368, 201-215. [CrossRef]

29. King, M.J.; Badea, I.; Solomon, J.; Kumar, P.; Gaspar, K.J.; Foldvari, M. Transdermal delivery of insulin from a novel biphasic lipid system in diabetic rats. Diabetes Technol. Ther. 2002, 4, 479-488. [CrossRef]

30. Zhang, Y.; Yu, J.; Kahkoska, A.R.; Wang, J.; Buse, J.B.; Gu, Z. Advances in transdermal insulin delivery. Adv. Drug Deliv. Rev. 2019, 139, 51-70. [CrossRef] [PubMed]

31. Jin, X.; Zhu, D.D.; Chen, B.Z.; Ashfaq, M.; Guo, X.D. Insulin delivery systems combined with microneedle technology. Adv. Drug Deliv. Rev. 2018, 127, 119-137. [CrossRef] [PubMed]

32. Gill, H.S.; Denson, D.D.; Burris, B.A.; Prausnitz, M.R. Effect of microneedle design on pain in human volunteers. Clin. J. Pain 2008, 24, 585-594. [CrossRef] [PubMed]

33. Sivamani, R.K.; Stoeber, B.; Wu, G.C.; Zhai, H.; Liepmann, D.; Maibach, H. Clinical microneedle injection of methyl nicotinate: Stratum corneum penetration. Skin Res. Technol. 2005, 11, 152-156. [CrossRef] [PubMed]

34. McAllister, D.V.; Wang, P.M.; Davis, S.P.; Park, J.H.; Canatella, P.J.; Allen, M.G.; Prausnitz, M.R. Microfabricated needles for transdermal delivery of macromolecules and nanoparticles: Fabrication methods and transport studies. Proc. Natl. Acad. Sci. USA 2003, 100, 13755-13760. [CrossRef]

35. Coulman, S.A.; Anstey, A.; Gateley, C.; Morrissey, A.; McLoughlin, P.; Allender, C.; Birchall, J.C. Microneedle mediated delivery of nanoparticles into human skin. Int. J. Pharm. 2009, 366, 190-200. [CrossRef] [PubMed]

36. Martanto, W.; Moore, J.S.; Kashlan, O.; Kamath, R.; Wang, P.M.; O’Neal, J.M.; Prausnitz, M.R. Microinfusion using hollow microneedles. Pharm. Res. 2006, 23, 104-113. [CrossRef] [PubMed]

37. Kaushik, S.; Hord, A.H.; Denson, D.D.; McAllister, D.V.; Smitra, S.; Allen, M.G.; Prausnitz, M.R. Lack of pain associated with microfabricated microneedles. Anesth. Analg. 2001, 92, 502-504. [CrossRef]

38. Prausnitz, M.R. Microneedles for transdermal drug delivery. Adv. Drug Deliv. Rev. 2004, 56, 581-587. [CrossRef] [PubMed]

39. Wu, Y.; Gao, Y.; Qin, G.; Zhang, S.; Qiu, Y.; Li, F.; Xu, B. Sustained release of insulin through skin by intradermal microdelivery system. Biomed. Microdevices 2010, 12, 665-671. [CrossRef] [PubMed]

40. Sullivan, S.P.; Koutsonanos, D.G.; Del Pilar Martin, M.; Lee, J.W.; Zarnitsyn, V.; Choi, S.O.; Murthy, N.; Compans, R.W.; Skountzou, I.; Prausnitz, M.R. Dissolving polymer microneedle patches for influenza vaccination. Nat. Med. 2010, 16, 915-920. [CrossRef] [PubMed]

41. Lee, J.W.; Park, J.H.; Prausnitz, M.R. Dissolving microneedles for transdermal drug delivery. Biomaterials 2008, 29 , $2113-2124$. [CrossRef] [PubMed]

42. Ling, M.H.; Chen, M.C. Dissolving polymer microneedle patches for rapid and efficient transdermal delivery of insulin to diabetic rats. Acta Biomater. 2013, 9, 8952-8961. [CrossRef] [PubMed]

43. Chen, M.C.; Ling, M.H.; Kusuma, S.J. Poly-gamma-glutamic acid microneedles with a supporting structure design as a potential tool for transdermal delivery of insulin. Acta Biomater. 2015, 24, 106-116. [CrossRef] [PubMed]

44. Ito, Y.; Nakahigashi, T.; Yoshimoto, N.; Ueda, Y.; Hamasaki, N.; Takada, K. Transdermal insulin application system with dissolving microneedles. Diabetes Technol. Ther. 2012, 14, 891-899. [CrossRef] [PubMed]

45. Liu, S.; Jin, M.N.; Quan, Y.S.; Kamiyama, F.; Katsumi, H.; Sakane, T.; Yamamoto, A. The development and characteristics of novel microneedle arrays fabricated from hyaluronic acid, and their application in the transdermal delivery of insulin. J. Control. Release 2012, 161, 933-941. [CrossRef] [PubMed]

46. Zhou, C.P.; Liu, Y.L.; Wang, H.L.; Zhang, P.X.; Zhang, J.L. Transdermal delivery of insulin using microneedle rollers in vivo. Int. J. Pharm. 2010, 392, 127-133. [CrossRef] [PubMed]

47. Chen, X.; Wang, L.; Yu, H.; Li, C.; Feng, J.; Haq, F.; Khan, A.; Khan, R.U. Preparation, properties and challenges of the microneedles-based insulin delivery system. J. Control. Release 2018, 288, 173-188. [CrossRef] [PubMed]

48. Liu, G.S.; Kong, Y.; Wang, Y.; Luo, Y.; Fan, X.; Xie, X.; Yang, B.R.; Wu, M.X. Microneedles for transdermal diagnostics: Recent advances and new horizons. Biomaterials 2020, 232, 119740. [CrossRef] [PubMed]

49. Wang, Y.; Wang, H.; Zhu, X.X.; Guan, Y.; Zhang, Y. Smart microneedle patches for rapid, and painless transdermal insulin delivery. J. Mater. Chem. B 2020, 8, 9335-9342. [CrossRef] [PubMed]

50. Zhang, Y.; Wu, M.; Tan, D.; Liu, Q.; Xia, R.; Chen, M.; Liu, Y.; Xue, L.; Lei, Y. A dissolving and glucose-responsive insulin-releasing microneedle patch for type 1 diabetes therapy. J. Mater. Chem. B 2020. [CrossRef]

51. Kim, S.; Yang, H.; Eum, J.; Ma, Y.; Lahiji, S.F.; Jung, H. Implantable powder-carrying microneedles for transdermal delivery of high-dose insulin with enhanced activity. Biomaterials 2020, 232, 119733. [CrossRef]

52. Gupta, J.; Gill, H.S.; Andrews, S.N.; Prausnitz, M.R. Kinetics of skin resealing after insertion of microneedles in human subjects. J. Control. Release 2011, 154, 148-155. [CrossRef]

53. Haq, M.I.; Smith, E.; John, D.N.; Kalavala, M.; Edwards, C.; Anstey, A.; Morrissey, A.; Birchall, J.C. Clinical administration of microneedles: Skin puncture, pain and sensation. Biomed. Microdevices 2009, 11, 35-47. [CrossRef] [PubMed]

54. Burton, S.A.; Ng, C.Y.; Simmers, R.; Moeckly, C.; Brandwein, D.; Gilbert, T.; Johnson, N.; Brown, K.; Alston, T.; Prochnow, G.; et al. Rapid intradermal delivery of liquid formulations using a hollow microstructured array. Pharm. Res. 2011, 28, 31-40. [CrossRef]

55. Bariya, S.H.; Gohel, M.C.; Mehta, T.A.; Sharma, O.P. Microneedles: An emerging transdermal drug delivery system. J. Pharm. Pharmacol. 2012, 64, 11-29. [CrossRef] [PubMed] 
56. Kovacik, A.; Kopecna, M.; Vavrova, K. Permeation enhancers in transdermal drug delivery: Benefits and limitations. Expert Opin. Drug Deliv. 2020, 17, 145-155. [CrossRef] [PubMed]

57. Sinha, V.R.; Kaur, M.P. Permeation enhancers for transdermal drug delivery. Drug Dev. Ind. Pharm. 2000, 26, 1131-1140. [CrossRef]

58. Karande, P.; Mitragotri, S. Enhancement of transdermal drug delivery via synergistic action of chemicals. Biochim. Biophys. Acta 2009, 1788, 2362-2373. [CrossRef]

59. Krishnaiah, Y.S.; Al-Saidan, S.M.; Chandrasekhar, D.V.; Rama, B. Effect of nerodilol and carvone on in vitro permeation of nicorandil across rat epidermal membrane. Drug Dev. Ind. Pharm. 2006, 32, 423-435. [CrossRef]

60. Ita, K.B. Chemical Penetration Enhancers for Transdermal Drug Delivery-Success and Challenges. Curr. Drug Deliv. 2015, 12, 645-651. [CrossRef]

61. Williams, A.C.; Barry, B.W. Penetration enhancers. Adv. Drug Deliv. Rev. 2004, 56, 603-618. [CrossRef] [PubMed]

62. Harjoh, N.; Wong, T.W.; Caramella, C. Transdermal insulin delivery with microwave and fatty acids as permeation enhancers. Int. J. Pharm. 2020, 584, 119416. [CrossRef]

63. Yerramsetty, K.M.; Rachakonda, V.K.; Neely, B.J.; Madihally, S.V.; Gasem, K.A. Effect of different enhancers on the transdermal permeation of insulin analog. Int. J. Pharm. 2010, 398, 83-92. [CrossRef] [PubMed]

64. Rastogi, R.; Anand, S.; Dinda, A.K.; Koul, V. Investigation on the synergistic effect of a combination of chemical enhancers and modulated iontophoresis for transdermal delivery of insulin. Drug Dev. Ind. Pharm. 2010, 36, 993-1004. [CrossRef] [PubMed]

65. Rastogi, S.K.; Singh, J. Effect of chemical penetration enhancer and iontophoresis on the in vitro percutaneous absorption enhancement of insulin through porcine epidermis. Pharm. Dev. Technol. 2005, 10, 97-104. [CrossRef] [PubMed]

66. Li, Y.Z.; Quan, Y.S.; Zang, L.; Jin, M.N.; Kamiyama, F.; Katsumi, H.; Yamamoto, A.; Tsutsumi, S. Transdermal delivery of insulin using trypsin as a biochemical enhancer. Biol. Pharm. Bull. 2008, 31, 1574-1579. [CrossRef]

67. Li, Y.Z.; Quan, Y.S.; Zang, L.; Jin, M.N.; Kamiyama, F.; Katsumi, H.; Tsutsumi, S.; Yamamoto, A. Trypsin as a novel potential absorption enhancer for improving the transdermal delivery of macromolecules. J. Pharm. Pharmacol. 2009, 61, 1005-1012. [CrossRef] [PubMed]

68. Priborsky, J.; Takayama, K.; Nagai, T.; Waitzova, D.; Elis, J. Combination effect of penetration enhancers and propylene glycol on in vitro transdermal absorption of insulin. Drug Des. Deliv. 1987, 2, 91-97.

69. Pillai, O.; Panchagnula, R. Transdermal iontophoresis of insulin. V. Effect of terpenes. J. Control. Release 2003, 88, 287-296. [CrossRef]

70. Pillai, O.; Panchagnula, R. Transdermal delivery of insulin from poloxamer gel: Ex vivo and in vivo skin permeation studies in rat using iontophoresis and chemical enhancers. J. Control. Release 2003, 89, 127-140. [CrossRef]

71. Isaac, M.; Holvey, C. Transdermal patches: The emerging mode of drug delivery system in psychiatry. Ther. Adv. Psychopharmacol. 2012, 2, 255-263. [CrossRef]

72. Kurmi, B.D.; Tekchandani, P.; Paliwal, R.; Paliwal, S.R. Transdermal Drug Delivery: Opportunities and Challenges for Controlled Delivery of Therapeutic Agents Using Nanocarriers. Curr. Drug Metab. 2017, 18, 481-495. [CrossRef] [PubMed]

73. Gandhi, K.; Dahiya, A.; Monika; Kalra, T.; Singh, K. Transdermal drug delivery-A review. Int. J. Res. Pharm. Sci. 2012, 3, 379-388.

74. Sudam, K.R.; Suresh, B.R. A Comprehensive Review on: Transdermal drug delivery systems. Int. J. Biomed. Adv. Res. 2016, 7, 147-159.

75. Pagneux, Q.; Ye, R.; Chengnan, L.; Barras, A.; Hennuyer, N.; Staels, B.; Caina, D.; Osses, J.I.A.; Abderrahmani, A.; Plaisance, V.; et al. Electrothermal patches driving the transdermal delivery of insulin. Nanoscale Horiz. 2020, 5, 663-670. [CrossRef] [PubMed]

76. King, M.J.; Michel, D.; Foldvari, M. Evidence for lymphatic transport of insulin by topically applied biphasic vesicles. J. Pharm. Pharmacol. 2003, 55, 1339-1344. [CrossRef]

77. Mbaye, G.; Ndiaye, A.; Diouf, L.A.; Diallo, A.S.; Diedhiou, A.; Sene, M.; Mbodj, M.; Thioune, O.; Dieye, A.M.; Diop, I.; et al. Development of Ethylcellulose/Eudragit matrix for controlled and continuous release of insulin. Mali. Med. 2009, 24, 11-16.

78. Bohannon, N.; Bergenstal, R.; Cuddihy, R.; Kruger, D.; List, S.; Massaro, E.; Molitch, M.; Raskin, P.; Remtema, H.; Strowig, S.; et al. Comparison of a novel insulin bolus-patch with pen/syringe injection to deliver mealtime insulin for efficacy, preference, and quality of life in adults with diabetes: A randomized, crossover, multicenter study. Diabetes Technol. Ther. 2011, 13, 1031-1037. [CrossRef]

79. Qiu, Y.; Qin, G.; Zhang, S.; Wu, Y.; Xu, B.; Gao, Y. Novel lyophilized hydrogel patches for convenient and effective administration of microneedle-mediated insulin delivery. Int. J. Pharm. 2012, 437, 51-56. [CrossRef] [PubMed]

80. Fukushima, K.; Yamazaki, T.; Hasegawa, R.; Ito, Y.; Sugioka, N.; Takada, K. Pharmacokinetic and pharmacodynamic evaluation of insulin dissolving microneedles in dogs. Diabetes Technol. Ther. 2010, 12, 465-474. [CrossRef] [PubMed]

81. Sibiya, N.; Ngubane, P.; Mabandla, M. Cardioprotective effects of pectin-insulin patch in streptozotocin-induced diabetic rats. J. Diabetes 2017, 9, 1073-1081. [CrossRef]

82. Seah, B.C.; Teo, B.M. Recent advances in ultrasound-based transdermal drug delivery. Int. J. Nanomed. 2018, 13, 7749-7763. [CrossRef] [PubMed]

83. Oberli, M.A.; Schoellhammer, C.M.; Langer, R.; Blankschtein, D. Ultrasound-enhanced transdermal delivery: Recent advances and future challenges. Ther. Deliv. 2014, 5, 843-857. [CrossRef]

84. Alkilani, A.Z.; McCrudden, M.T.; Donnelly, R.F. Transdermal Drug Delivery: Innovative Pharmaceutical Developments Based on Disruption of the Barrier Properties of the stratum corneum. Pharmaceutics 2015, 7, 438-470. [CrossRef] [PubMed] 
85. Alvarez-Roman, R.; Merino, G.; Kalia, Y.N.; Naik, A.; Guy, R.H. Skin permeability enhancement by low frequency sonophoresis: Lipid extraction and transport pathways. J. Pharm. Sci. 2003, 92, 1138-1146. [CrossRef]

86. Jabbari, N.; Asghari, M.H.; Ahmadian, H.; Mikaili, P. Developing a Commercial Air Ultrasonic Ceramic Transducer to Transdermal Insulin Delivery. J. Med. Signals Sens. 2015, 5, 117-122.

87. Feiszthuber, H.; Bhatnagar, S.; Gyongy, M.; Coussios, C.C. Cavitation-enhanced delivery of insulin in agar and porcine models of human skin. Phys. Med. Biol. 2015, 60, 2421-2434. [CrossRef]

88. Park, E.J.; Dodds, J.; Smith, N.B. Dose comparison of ultrasonic transdermal insulin delivery to subcutaneous insulin injection. Int. J. Nanomed. 2008, 3, 335-341.

89. Murthy, S.N.; Sen, A.; Zhao, Y.L.; Hui, S.W. Temperature influences the postelectroporation permeability state of the skin. J. Pharm. Sci. 2004, 93, 908-915. [CrossRef]

90. Mohammad, E.A.; Elshemey, W.M.; Elsayed, A.A.; Abd-Elghany, A.A. Electroporation Parameters for Successful Transdermal Delivery of Insulin. Am. J. Ther. 2016, 23, e1560-e1567. [CrossRef]

91. Tokumoto, S.; Higo, N.; Sugibayashi, K. Effect of electroporation and pH on the iontophoretic transdermal delivery of human insulin. Int. J. Pharm. 2006, 326, 13-19. [CrossRef]

92. Murthy, S.N.; Zhao, Y.L.; Marlan, K.; Hui, S.W.; Kazim, A.L.; Sen, A. Lipid and electroosmosis enhanced transdermal delivery of insulin by electroporation. J. Pharm. Sci. 2006, 95, 2041-2050. [CrossRef]

93. Rawat, S.; Vengurlekar, S.; Rakesh, B.; Jain, S.; Srikarti, G. Transdermal delivery by iontophoresis. Indian J. Pharm. Sci. 2008, 70, 5-10. [CrossRef]

94. Vranic, E. Iontophoresis: Fundamentals, developments and application. Bosn. J. Basic Med. Sci. 2003, 3, 54-58. [CrossRef] [PubMed]

95. Dhote, V.; Bhatnagar, P.; Mishra, P.K.; Mahajan, S.C.; Mishra, D.K. Iontophoresis: A potential emergence of a transdermal drug delivery system. Sci. Pharm. 2012, 80, 1-28. [CrossRef]

96. Hao, J.S.; Zheng, J.M.; Yang, W.Z. Transdermal iontophoresis of insulin: Effect of penetration enhancers on blood glucose level in diabetic rats. Yao Xue Xue Bao 1995, 30, 776-780.

97. Pan, Y.; Zhao, H.Y.; Zheng, J.M. The enhancing effect of electroporation and iontophoresis on the permeation of insulin through human skin. Yao Xue Xue Bao 2002, 37, 649-652.

98. Langkjaer, L.; Brange, J.; Grodsky, G.M.; Guy, R.H. Iontophoresis of monomeric insulin analogues in vitro: Effects of insulin charge and skin pretreatment. J. Control. Release 1998, 51, 47-56. [CrossRef]

99. Kajimoto, K.; Yamamoto, M.; Watanabe, M.; Kigasawa, K.; Kanamura, K.; Harashima, H.; Kogure, K. Noninvasive and persistent transfollicular drug delivery system using a combination of liposomes and iontophoresis. Int. J. Pharm. 2011, 403, 57-65. [CrossRef] [PubMed]

100. Chen, H.; Zhu, H.; Zheng, J.; Mou, D.; Wan, J.; Zhang, J.; Shi, T.; Zhao, Y.; Xu, H.; Yang, X. Iontophoresis-driven penetration of nanovesicles through microneedle-induced skin microchannels for enhancing transdermal delivery of insulin. J. Control. Release 2009, 139, 63-72. [CrossRef]

101. Akbarzadeh, A.; Rezaei-Sadabady, R.; Davaran, S.; Joo, S.W.; Zarghami, N.; Hanifehpour, Y.; Samiei, M.; Kouhi, M.; Nejati-Koshki, K. Liposome: Classification, preparation, and applications. Nanoscale Res. Lett. 2013, 8, 102-111. [CrossRef] [PubMed]

102. Biju, S.S.; Talegaonkar, S.; Mishra, P.R.; Khar, R.K. Vesicular systems: An overview. Indian J. Pharm. Sci. 2006, 68, 141-153.

103. Ogiso, T.; Nishioka, S.; Iwaki, M. Dissociation of insulin oligomers and enhancement of percutaneous absorption of insulin. Biol. Pharm. Bull. 1996, 19, 1049-1054. [CrossRef]

104. Cevc, G. Transdermal drug delivery of insulin with ultradeformable carriers. Clin. Pharmacokinet. 2003, 42, 461-474. [CrossRef] [PubMed]

105. Marwah, H.; Garg, T.; Rath, G.; Goyal, A.K. Development of transferosomal gel for trans-dermal delivery of insulin using iodine complex. Drug Deliv. 2016, 23, 1636-1644. [CrossRef]

106. Malakar, J.; Sen, S.O.; Nayak, A.K.; Sen, K.K. Formulation, optimization and evaluation of transferosomal gel for transdermal insulin delivery. Saudi Pharm. J. 2012, 20, 355-363. [CrossRef] [PubMed]

107. Date, A.A.; Patravale, V.B. Microemulsions: Applications in transdermal and dermal delivery. Crit. Rev. Ther. Drug Carr. Syst. 2007, 24, 547-596.

108. Shukla, T.; Upmanyu, N.; Agrawal, M.; Saraf, S.; Alexander, A. Biomedical applications of microemulsion through dermal and transdermal route. Biomed. Pharmacother. 2018, 108, 1477-1494. [CrossRef]

109. Santos, P.; Watkinson, A.C.; Hadgraft, J.; Lane, M.E. Application of microemulsions in dermal and transdermal drug delivery. Skin Pharmacol. Physiol. 2008, 21, 246-259. [CrossRef] [PubMed]

110. Akram, M.; Naqvi, S.B.; Khan, A. Design and development of insulin emulgel formulation for transdermal drug delivery and its evaluation. Pak. J. Pharm. Sci. 2013, 26, 323-332. [PubMed]

111. Malakar, J.; Sen, S.O.; Nayak, A.K.; Sen, K.K. Development and evaluation of microemulsions for transdermal delivery of insulin. ISRN Pharm. 2011, 2011, 780150. [CrossRef] [PubMed]

112. Ghasemiyeh, P.; Mohammadi-Samani, S. Potential of Nanoparticles as Permeation Enhancers and Targeted Delivery Options for Skin: Advantages and Disadvantages. Drug Des. Dev. Ther. 2020, 14, 3271-3289. [CrossRef] [PubMed]

113. Lauterbach, A.; Muller-Goymann, C.C. Applications and limitations of lipid nanoparticles in dermal and transdermal drug delivery via the follicular route. Eur. J. Pharm. Biopharm. 2015, 97, 152-163. [CrossRef] [PubMed] 
114. Kakadia, P.G.; Conway, B.R. Lipid nanoparticles for dermal drug delivery. Curr. Pharm. Des. 2015, 21, 2823-2829. [CrossRef] [PubMed]

115. Zhao, X.; Zu, Y.; Zu, S.; Wang, D.; Zhang, Y.; Zu, B. Insulin nanoparticles for transdermal delivery: Preparation and physicochemical characterization and in vitro evaluation. Drug Dev. Ind. Pharm. 2010, 36, 1177-1185. [CrossRef] [PubMed]

116. Andrews, S.; Lee, J.W.; Choi, S.O.; Prausnitz, M.R. Transdermal insulin delivery using microdermabrasion. Pharm. Res. 2011, 28, 2110-2118. [CrossRef]

117. Marwah, H.; Garg, T.; Goyal, A.K.; Rath, G. Permeation enhancer strategies in transdermal drug delivery. Drug Deliv. 2016, 23, 564-578. [CrossRef] [PubMed]

118. Mitragotri, S.; Blankschtein, D.; Langer, R. Transdermal drug delivery using low-frequency sonophoresis. Pharm. Res. 1996, 13, 411-420. [CrossRef] [PubMed]

119. Lavon, I.; Kost, J. Ultrasound and transdermal drug delivery. Drug Discov. Today 2004, 9, 670-676. [CrossRef]

120. Boucaud, A.; Garrigue, M.A.; Machet, L.; Vaillant, L.; Patat, F. Effect of sonication parameters on transdermal delivery of insulin to hairless rats. J. Control. Release 2002, 81, 113-119. [CrossRef]

121. Schlicher, R.K.; Radhakrishna, H.; Tolentino, T.P.; Apkarian, R.P.; Zarnitsyn, V.; Prausnitz, M.R. Mechanism of intracellular delivery by acoustic cavitation. Ultrasound Med. Biol. 2006, 32, 915-924. [CrossRef] [PubMed]

122. Park, D.; Park, H.; Seo, J.; Lee, S. Sonophoresis in transdermal drug deliverys. Ultrasonics 2014, 54, 56-65. [CrossRef] [PubMed]

123. Ita, K. Perspectives on Transdermal Electroporation. Pharmaceutics 2016, 8, 9. [CrossRef]

124. Chen, X.; Zhu, L.; Li, R.; Pang, L.; Zhu, S.; Ma, J.; Du, L.; Jin, Y. Electroporation-enhanced transdermal drug delivery: Effects of $\log \mathrm{P}, \mathrm{pKa}$, solubility and penetration time. Eur. J. Pharm. Sci. 2020, 151, 105410. [CrossRef] [PubMed]

125. Akhtar, N.; Singh, V.; Yusuf, M.; Khan, R.A. Non-invasive drug delivery technology: Development and current status of transdermal drug delivery devices, techniques and biomedical applications. Biomed. Tech. Eng. 2020, 65, 243-272. [CrossRef] [PubMed]

126. Dermol-Cerne, J.; Pirc, E.; Miklavcic, D. Mechanistic view of skin electroporation-models and dosimetry for successful applications: An expert review. Expert Opin. Drug Deliv. 2020, 17, 689-704. [CrossRef]

127. Rastogi, R.; Anand, S.; Koul, V. Electroporation of polymeric nanoparticles: An alternative technique for transdermal delivery of insulin. Drug Dev. Ind. Pharm. 2010, 36, 1303-1311. [CrossRef]

128. Batheja, P.; Thakur, R.; Michniak, B. Transdermal iontophoresis. Expert Opin. Drug Deliv. 2006, 3, 127-138. [PubMed]

129. Panchagnula, R.; Pillai, O.; Nair, V.B.; Ramarao, P. Transdermal iontophoresis revisited. Curr. Opin. Chem. Biol. 2000, 4, 468-473. [CrossRef]

130. Pillai, O.; Kumar, N.; Dey, C.S.; Borkute, S.; Nagalingam, S.; Panchagnula, R. Transdermal iontophoresis of insulin. Part 1: A study on the issues associated with the use of platinum electrodes on rat skin. J. Pharm. Pharmacol. 2003, 55, 1505-1513. [CrossRef] [PubMed]

131. Pillai, O.; Kumar, N.; Dey, C.S.; Borkute; Sivaprasad, N.; Panchagnula, R. Transdermal iontophoresis of insulin: III. Influence of electronic parameters. Methods Find. Exp. Clin. Pharmacol. 2004, 26, 399-408. [PubMed]

132. Pillai, O.; Nair, V.; Panchagnula, R. Transdermal iontophoresis of insulin: IV. Influence of chemical enhancers. Int. J. Pharm. 2004, 269, 109-120. [CrossRef] [PubMed]

133. Pillai, O.; Panchagnula, R. Transdermal iontophoresis of insulin. VI. Influence of pretreatment with fatty acids on permeation across rat skin. Skin Pharmacol. Physiol. 2004, 17, 289-297. [CrossRef] [PubMed]

134. Li, Y.; Cong, H.; Wang, S.; Yu, B.; Shen, Y. Liposomes modified with bio-substances for cancer treatment. Biomater. Sci. 2020, 23, 6442-6468. [CrossRef] [PubMed]

135. Shah, S.; Dhawan, V.; Holm, R.; Nagarsenker, M.S.; Perrie, Y. Liposomes: Advancements and innovation in the manufacturing process. Adv. Drug Deliv. Rev. 2020, 154-155, 102-122. [CrossRef]

136. Pace, J.R.; Jog, R.; Burgess, D.J.; Hadden, M.K. Formulation and evaluation of itraconazole liposomes for Hedgehog pathway inhibition. J. Liposome Res. 2020, 30, 305-311. [CrossRef] [PubMed]

137. Rai, S.; Pandey, V.; Rai, G. Transfersomes as versatile and flexible nano-vesicular carriers in skin cancer therapy: The state of the art. Nano Rev. Exp. 2017, 8, 1325708. [CrossRef]

138. Ita, K. Current Status of Ethosomes and Elastic Liposomes in Dermal and Transdermal Drug Delivery. Curr. Pharm. Des. 2016, 22, 5120-5126. [CrossRef]

139. Kumar, A.; Pathak, K.; Bali, V. Ultra-adaptable nanovesicular systems: A carrier for systemic delivery of therapeutic agents. Drug Discov. Today 2012, 17, 1233-1241. [CrossRef] [PubMed]

140. Peltola, S.; Saarinen-Savolainen, P.; Kiesvaara, J.; Suhonen, T.M.; Urtti, A. Microemulsions for topical delivery of estradiol. Int. J. Pharm. 2003, 254, 99-107. [CrossRef]

141. El Maghraby, G.M. Self-microemulsifying and microemulsion systems for transdermal delivery of indomethacin: Effect of phase transition. Colloids Surf. B Biointerfaces 2010, 75, 595-600. [CrossRef] [PubMed]

142. Sintov, A.C.; Botner, S. Transdermal drug delivery using microemulsion and aqueous systems: Influence of skin storage conditions on the in vitro permeability of diclofenac from aqueous vehicle systems. Int. J. Pharm. 2006, 311, 55-62. [CrossRef] [PubMed]

143. El Maghraby, G.M. Transdermal delivery of hydrocortisone from eucalyptus oil microemulsion: Effects of cosurfactants. Int. J. Pharm. 2008, 355, 285-292. [CrossRef] [PubMed] 
144. Zhu, J.; Tang, X.; Jia, Y.; Ho, C.T.; Huang, Q. Applications and delivery mechanisms of hyaluronic acid used for topi$\mathrm{cal} /$ transdermal delivery-A review. Int. J. Pharm. 2020, 578, 119127. [CrossRef] [PubMed]

145. Russell-Jones, G.; Himes, R. Water-in-oil microemulsions for effective transdermal delivery of proteins. Expert Opin. Drug Deliv. 2011, 8, 537-546. [CrossRef] [PubMed]

146. Ferreira, P.G.; Noronha, L.; Teixeira, R.; Vieira, I.; Borba-Santos, L.P.; Vicosa, A.; de Moraes, M.; Calil-Elias, S.; de Freitas, Z.; da Silva, F.C.; et al. Investigation of a Microemulsion Containing Clotrimazole and Itraconazole for Transdermal Delivery for the Treatment of Sporotrichosis. J. Pharm. Sci. 2020, 109, 1026-1034. [CrossRef]

147. Zhang, Y.; Cao, Y.; Meng, X.; Li, C.; Wang, H.; Zhang, S. Enhancement of transdermal delivery of artemisinin using microemulsion vehicle based on ionic liquid and lidocaine ibuprofen. Colloids Surf. B Biointerfaces 2020, 189, 110886. [CrossRef] [PubMed]

148. Laothaweerungsawat, N.; Neimkhum, W.; Anuchapreeda, S.; Sirithunyalug, J.; Chaiyana, W. Transdermal delivery enhancement of carvacrol from Origanum vulgare L. essential oil by microemulsion. Int. J. Pharm. 2020, 579, 119052. [CrossRef] [PubMed]

149. Bhalla, M.; Thami, G.P. Microdermabrasion: Reappraisal and brief review of literature. Dermatol. Surg. 2006, 32, 809-814. [CrossRef]

150. Fujimoto, T.; Shirakami, K.; Tojo, K. Effect of microdermabrasion on barrier capacity of stratum corneum. Chem. Pharm. Bull. (Tokyo) 2005, 53, 1014-1016. [CrossRef] [PubMed]

151. Freedman, B.M.; Rueda-Pedraza, E.; Waddell, S.P. The epidermal and dermal changes associated with microdermabrasion. Dermatol. Surg. 2001, 27, 1031-1034.

152. Lee, W.R.; Shen, S.C.; Kuo-Hsien, W.; Hu, C.H.; Fang, J.Y. Lasers and microdermabrasion enhance and control topical delivery of vitamin C. J. Investig. Dermatol. 2003, 121, 1118-1125. [CrossRef] [PubMed]

153. Fang, J.Y.; Lee, W.R.; Shen, S.C.; Fang, Y.P.; Hu, C.H. Enhancement of topical 5-aminolaevulinic acid delivery by erbium:YAG laser and microdermabrasion: A comparison with iontophoresis and electroporation. Br. J. Dermatol. 2004, 151, 132-140. [CrossRef] [PubMed]

154. Lee, W.R.; Tsai, R.Y.; Fang, C.L.; Liu, C.J.; Hu, C.H.; Fang, J.Y. Microdermabrasion as a novel tool to enhance drug delivery via the skin: An animal study. Dermatol. Surg. 2006, 32, 1013-1022. [CrossRef]

155. Gill, H.S.; Andrews, S.N.; Sakthivel, S.K.; Fedanov, A.; Williams, I.R.; Garber, D.A.; Priddy, F.H.; Yellin, S.; Feinberg, M.B.; Staprans, S.I.; et al. Selective removal of stratum corneum by microdermabrasion to increase skin permeability. Eur. J. Pharm. Sci. 2009, 38, 95-103. [CrossRef] [PubMed] 